\title{
9. Re/forming laws to secure women's rights in Turkey: the campaign on the Penal Code
}

\author{
PINAR ILKKARACAN
}

On 26 September 2004, a draft law aimed at the reform of the Turkish Penal Code was accepted in the Turkish parliament as the result of a three-year campaign led by a platform of women's and lesbian, gay, bisexual and transgender (LGBT) organizations, the Women's Platform on the Turkish Penal Code (WPTPC). The campaign secured thirty-five amendments towards recognition of women's legal entitlement to sexual and bodily autonomy and rights despite strong opposition from the right-wing, Islamist Adalet ve Kalkınma Partisi (AKP, Justice and Development Party) government. It aimed to transform the underlying philosophy and principles of the old Penal Code, which constructed women's bodies and sexuality as belonging to their families, fathers, husbands and society; to eliminate all articles that constituted violations of women's human rights, particularly sexual and bodily rights; and to ensure progressive definitions of sexual crimes. This signified a groundbreaking shift in the overall perspective of the Turkish state and the public on the issue. The campaign occupied the public agenda for three years, generated wide discussion and broke taboos on issues related to sexuality.

This chapter provides a critical account of the campaign, its actors and the factors that contributed to its success. It draws on the author's personal experience as the co-founder of the Women's Working Group on the Penal Code (WWGPC), which initiated the campaign; and coordinator of the NGO Women for Women's Human Rights - New Ways (WWHR New Ways), which acted as the coordinating body throughout.

\section{The historical and political context: women and civil society in Turkey}

Primary education has been mandatory in Turkey since 1924, but 32 per cent of women are still illiterate (State Statistics Institute 1986). The percentage of paid women workers is still a mere 16.1 in urban areas (Ministry for Women's Affairs and Social Services 1994). The representation of women in parliament remains under 10 per cent. Yet the official 
discourse of the state holds that the problem of the status of women has been solved and that Turkish women should consider themselves lucky because they were granted specific rights in the public sphere even before their European counterparts.

The founding of the Turkish Republic in 1923 after the war of independence was followed by the introduction of several revolutionary reforms, including drastic changes regarding equality of women and men in the legal sphere; secularization of the state; the abolition of the Sultanate, the sharia (Islamic religious law) and the caliphate; and the adoption of Latin letters as the Turkish alphabet. ${ }^{1}$ In 1926 the introduction of the Turkish Civil Code, modelled on the Swiss Civil Code, banned polygamy and granted women equal rights in matters of divorce and child custody. The Civil Code in particular was an important victory over advocates of sharia. However, even this widely acknowledged and celebrated reform of the Turkish Civil Code, which has been predominantly regarded as progressive both in academic circles and among the Turkish public, was far from bringing actual equality for women in Turkey. Until the reform of the Civil Code in 2001, several laws, especially those in the marriage and family section of the old Civil Code, reduced women to a subordinate position. For example, the husband was defined as the head of the marriage union, granting him the final say over the choice of domicile, and over issues concerning children.

This state discourse on the status of women has been internalized by many of the women who have been able to benefit from the new possibilities of the young republic, such as professional women living in big cities or women of the bureaucratic elite. Consequently, most women's groups and associations formed during the post-republican era have concentrated on 'helping' or 'educating' women in rural areas, instead of questioning their own status or pressing for further rights. Moreover, the dichotomy they have perceived between themselves and rural women has hindered their understanding of the problems and potentials of these women, reducing the effectiveness of their efforts.

In the 1960 s and 1970s, right- and left-wing political movements dominated Turkish political debate and activity in reaction to strong state controls. Women's issues and activists were subsumed into the Marxist movement and its discourses. The 1970s witnessed an armed conflict between right- and left-wing groups, resulting in tragic violence and the deaths of hundreds of activists and civilians. The 1980 military intervention, justified by the military as the only way to end the anarchic atmosphere, suppressed leftist opposition by force, while also systematically depoliticizing the masses and setting the stage for 
neoliberal policies proposed by the International Monetary Fund and other capitalist forces. In this atmosphere of repression and fear, the first new social movement to articulate its demands and oppose the government was the women's movement. ${ }^{2}$

Since 1980, several factors have weakened state authority and control in social life, thereby enabling the development of civil society in Turkey. Transition towards a free-market-based economy, political and cultural conflicts and globalization have all led to the rise and development of a civil society with autonomy vis-à-vis the state. A major research study on the status and progress of civil society in Turkey notes that in this context women's organizations deserve particular attention for their success (Bikmen and Meydanoğlu 2006).

The new feminist movement of the 1980 s brought private-sphere women's human rights violations in Turkey to public attention for the first time, initially campaigning on domestic violence. In 1989 another widespread and energetic feminist campaign followed against sexual harassment and sexual violence. This brought an important achievement in the legal arena. Article 438 of the Turkish Penal Code, which reduced by one-third the sentence given to rapists if the victim was a sex worker, was repealed by the Grand National Assembly in 1990. A law aimed at protecting victims of domestic violence was passed in 1998 as a result of another feminist campaign. ${ }^{3}$

Throughout the 1990s, feminist advocacy and lobbying for legal reform concentrated mainly on the reform of the Civil Code, which contained several provisions violating both the constitutional guarantee of gender equality and international conventions to which Turkey was a signatory, such as the Convention on the Elimination of All Forms of Discrimination Against Women (CEDAW). ${ }^{4}$

Although the reform of the Civil Code and amendments for gender equality first got on to the agenda of the Turkish parliament in the 1950s, none of the reform attempts was conclusive until the fully fledged reform of the Civil Code in 2001, the result of a broad and intensive campaign by the women's movement. This was achieved after a decade of campaigning. Conditions appeared favourable: the government was well disposed to the women's movement's demands and European Union accession prospects were expected to intimidate opponents of gender equality. Nevertheless, male members of parliament (MPs) rebelled against their own government to overturn the proposed gender equality provisions. The women's movement responded with a large-scale campaign which influenced public opinion and eventually contributed to the approval of a new Civil Code in November 2001, which abolished 